\title{
The Potential of a Low Cost Technology for The Greywater Treatment
}

\author{
Francis W. Kariuki*, Kiplagat Kotut and Victor G. Ngángá \\ Kenyatta University, Department of Plant and Microbial Science, P.O. Box 43844 Nairobi, Kenya
}

\begin{abstract}
Greywater (GW) is household wastewater effluent originating from baths, showers, kitchen and hand wash basins and laundry and constitutes $50-80 \%$ of indoor household water use. It represents water that can potentially be intercepted at the household level for use. In Kenya, GW use is practiced on an informal basis to supplement irrigation water, either in urban gardens in middle to upper income suburbs or in food gardens in lower income informal, periurban and rural areas. However, the reuse of greywater for irrigation without any significant pre-treatment poses a potential risk to both human and environmental health due to microbial and chemical contamination. This study investigated the potential of a low cost greywater treatment (GWT) system for safe greywater reuse by households. The system comprises of discrete units of barrels that allows for filtration, flocculation, sedimentation and disinfection. GWT system produced water with both $\mathrm{pH}$ and electrical conductivity suitable for irrigation according to WHO guidelines. It was also efficient at eliminating Salmonella sp. and reducing total coli form in composite greywater from households in Homa Bay after the effluent was disinfected with commercial disinfectant, sodium hypochlorite $(\mathrm{NaOCl})$. The cleaned greywater had a total coli form count $\left(2.5 \times 10^{6} \mathrm{cfu} / 100 \mathrm{ml}\right)$ comparable to $0->2.4 \times 10^{6} \mathrm{cfu} / 100 \mathrm{ml}$ obtained when greywater was treated using an expensive biological aerated filter (BAF). Fecal coli form counts $\left(2.1 \times 10^{2} \mathrm{cfu} / 100 \mathrm{ml}\right)$ compare well with $10^{3} \mathrm{cfu} / 100$ $\mathrm{ml}$ provided in WHO guidelines for public parks and crops likely to be eaten uncooked. The treatment had no effect on dissolved oxygen, $\mathrm{pH}$, salinity and electrical conductivity. The study concludes that the GWT system can be a sustainable and promising low cost low technology treatment system that can be run and maintained by unskilled operators.
\end{abstract}

Keywords: Low cost technology, Greywater treatment, Flocculation, Disinfection.

\section{INTRODUCTION}

For centuries man's built environment and quality of life has been closely predicated on the availability and sustainability of natural resources. As the common denominator in virtually every ecosystem, water resources serve as the cornerstone of human society and its sustenance. Access to water supply and improved sanitation is one of key factors in improving health and economic productivity. Yet the global demand for water increasingly exceeds the limits of supply, compromising man's quality of life and very existence [1]. Although a sustainable supply of water is essential for socioeconomic development, the water resources in today's society have been wasted and mismanaged by overconsumption and pollution [2, 3]. The number of people currently living under water stress is 700 million and this number is projected to reach the 3 billion mark in 2035 [4] and as new sources of water supply become increasingly scarce, expensive, or politically controversial, the need for sustainable water use has emerged and efforts are underway to identify new ways of meeting water needs.

A water sector issue of prime importance is the domestic wastewater and its sanitation since despite the efforts undertaken so far, 2.6 billion people still lack access to

\footnotetext{
*Address correspondence to this author at the Kenyatta University, Department of Plant and Microbial Science, P.O. Box 43844 Nairobi, Kenya;

Tel: 0721 457747: Fax: +254-020-811575/811242;

E-mail: franciskrk@yahoo.com
}

sanitation facilities [5]. The currently adopted centralized urban sanitation concept is costly in terms of construction, treatment and maintenance [6] and focuses on the quality of the effluent without considering the value of domestic wastewater components; i.e. organic matter, nitrogen, and phosphorous. In response, various new concepts have been developed that view domestic wastewater streams as a resource of water, nutrients and organic matter that could be recovered by on-site source separation, treatment and reclamation $[6,7]$.

Additionally, the water needs of a growing population go hand in hand with an improvement of living standards, while at the same time the increased demand must not overexploit the valuable resource itself. However, fundamental is the perception that freshwater is required to meet all demands for water, whether drinking or irrigation resulting in the demand for freshwater, straining the financial and natural resources. This water consumption paradigm needs to shift to one which converts freshwater uses and users to water uses and users and thus reduce pressure on the freshwater reserves and demands since water of the highest quality is only needed for drinking and cooking, making up about $5 \%$ of the current total consumption [6]. This shift will require that alternative sources of water are identified, and appropriate technologies are developed to harness them.

Alternative water sources available include rainwater, sea and brackish water, greywater, and domestic/municipal wastewater. Among these, greywater represents the most 


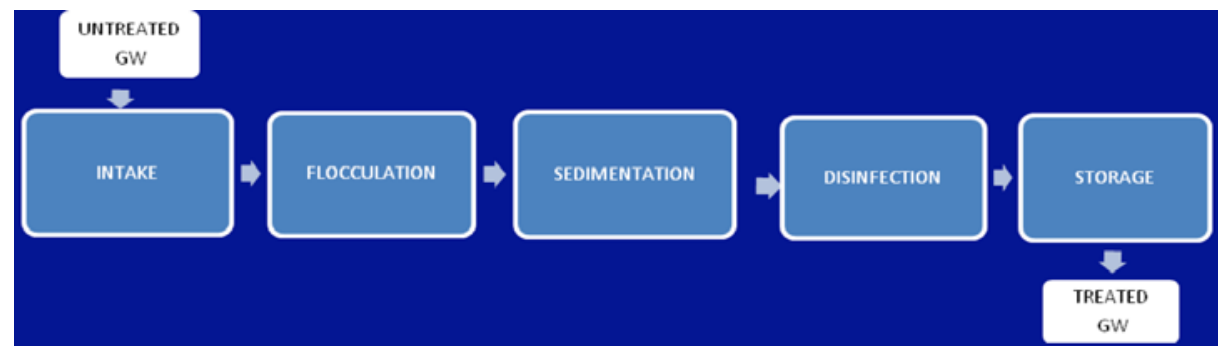

Fig. (1). Schematic diagram of a low cost greywater treatment system.

profitable source in terms of its reliability, availability and raw water quality $[8,9]$. Greywater (GW) is generally defined as low strength polluted wastewater originating from bathtubs, showers, hand washing basins and washing machines but excluding wastewater from the kitchen and the toilet flushing system [10]. GW contains an easily biodegradable organic content and a relatively low pathogens content $[11,12]$, making it much easier to treat and safer to recycle for water uses that do not need potable water quality, such as toilet flushing, urban landscaping or road washing. As water is becoming a rare resource, the onsite reuse and recycling of greywater is practiced in many countries as a sustainable solution to reduce the overall urban water demand [13-15]. In developing countries, the reuse of greywater for irrigation is becoming increasingly common and is often used without any significant pre-treatment, a practice mistakenly considered safe [1], though this form of application can damage soil health [15]. Although greywater is not likely to contain disease organisms of the same magnitude as those in blackwater, microbial and chemical contamination of greywater also poses a potential risk to human health. It is therefore important to recognize that greywater does have the potential to transmit disease [7] and therefore requires treatment and disinfection to inactivate the pathogenic microorganisms.

As long as there is potable water consumption, greywater could provide a reliable and perennial water source. Reuse of treated greywater which amounts to two thirds of the total domestic wastewater produced, could save the limited sources of freshwater. Even if reuse of greywater is not considered a priority (for reasons of abundance of freshwater resources or cultural barriers), appropriate greywater treatment prior to its discharge could significantly reduce water pollution and therefore, significantly contribute to protecting the environment and improving public health and living conditions of communities relying on these freshwater sources. Experience in several countries also indicates that greywater can be a cost effective alternative source of water [4].

Water scarcity, poor water quality and water-related disasters are the three main concerns related to current and future water resources [16]. Improving water quality and mitigating water scarcity are closely linked to greywater management. As awareness of the potential and challenges associated with greywater disposal become apparent, more attention need to be placed on treatment and use at the household level through low cost treatment technologies. A number of technologies have been developed for greywater treatment worldwide, varying in both complexity and performance. However, a drawback to their adoption in developing coun- tries has been the high initial investment costs which can be mitigated by more appropriate simple low-technology and efficient treatment systems. Low cost technologies have been used for greywater recycling ranging from simple 2-stage processes (coarse filtration and disinfection) to physical, physico-chemical and biological processes [12]. The objective of this study was therefore to develop and pilot test a low cost household level greywater treatment (GWT) system.

\section{MATERIALS AND METHODS}

\section{Greywater Treatment System (GWT)}

A 5-barrel greywater treatment (GWT) system consisting of 5 recycled polyethylene (PE) plastics barrels connected together by polyvinyl chloride (PVC) pipes was developed (Fig. 1). The flow of greywater within the system was through gravity and was controlled with valves. Pretreatment takes place in 100 litre barrel where oil, grease and food particles and other suspended solids (soil, hair and lint) are filtered by ordinary sieves placed at the mouth of each barrel. Filtered GW then passes from the pretreatment barrel through a pipe fitted with a filter (pore size: $0.45 \mathrm{~mm}$, Sartorius) into the second and third PE barrels each of which had a capacity of 200 litres. In the second barrel, rock alum (aluminum sulphate) was added to the GW and allowed to stand for at least 8 hours before being let into the third barrel where disinfection takes place. After disinfection with sodium hypochlorite $(\mathrm{NaOCl})$, the water is allowed to stand for 30 minutes and thereafter allowed to flow into the storage barrel ready for reuse.

\section{Pilot Testing of GWT}

Greywater (GW) was collected from Kenyatta University kitchen and students ' laundry uses was used to pilot test the treatment system. Samples were collected on the day of production (within 1 hour) from the two sources on various dates between October 2008 and February 2009. A 5-litre alcohol-rinsed open-mouthed container was used for the actual collection from kitchen sinks and washing basins before being emptied into three (3) 20-litre black insulated containers and immediately transported to the department of Plant and Microbial Sciences treatment site for analysis and treatment. The collection and transportation of GW was conducted in accordance with the aseptic sampling techniques [17]. At the treatment site, samples were immediately analyzed for the initial electrical conductivity (EC), $\mathrm{pH}$ and total coli forms. EC and $\mathrm{pH}$ were measured using a Universal Multiline P4 WTW (Wilheim, Germany) meter. Rapid testing of GW for the presence of total coli forms employed the 

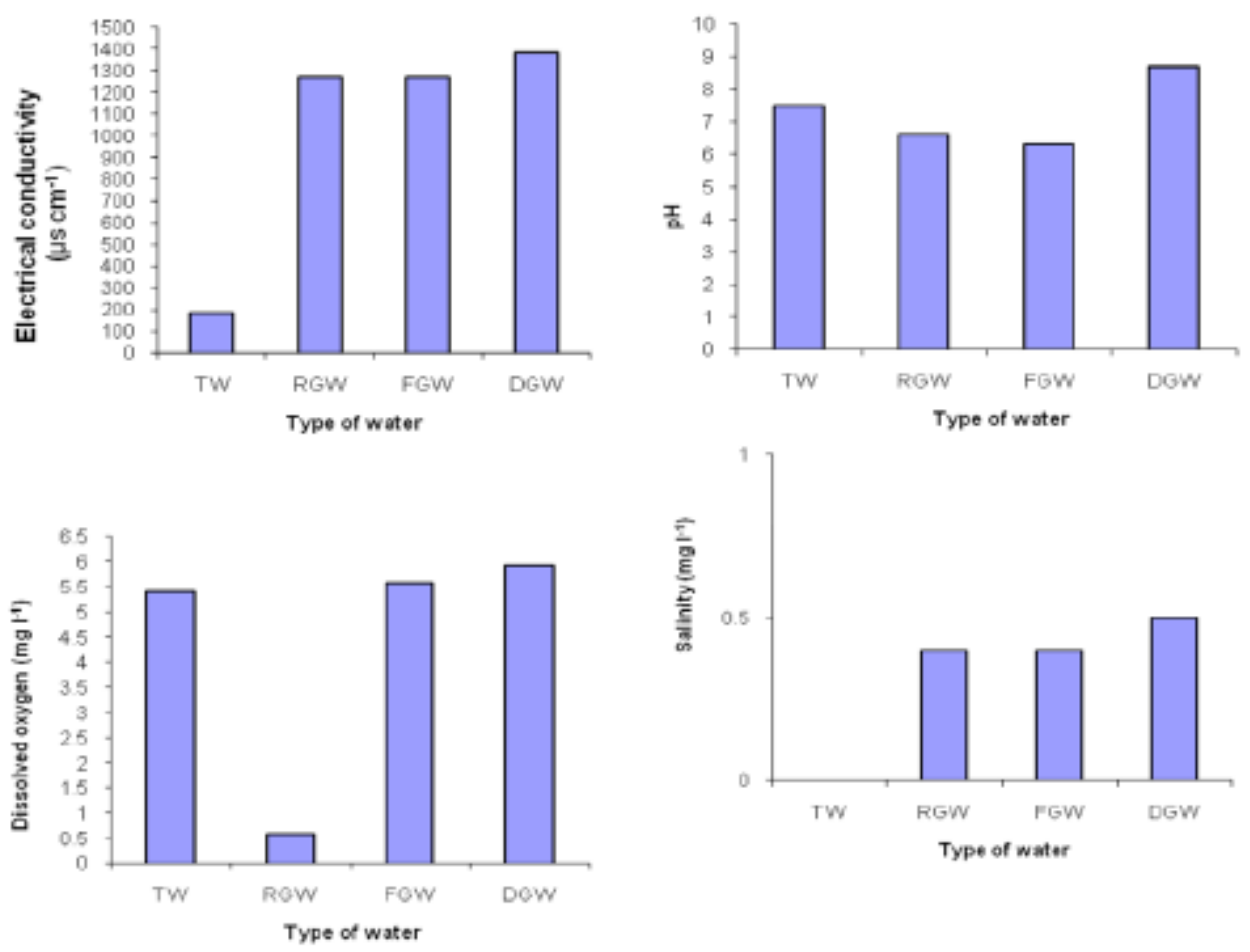

Fig. (2). Some Physical characteristics of tap water (TW) and raw (RGW) flocculated (FGW) and disinfected composite greywater (DGW) from Homa Bay households.

multiple tube fermentation technique [18]. This technique has two steps, the presumptive and the confirmed tests. In the presumptive test, three sets of five tubes containing different portions of water samples were inoculated in sterile Laury tryptose broth and incubated at $37^{\circ} \mathrm{C}$ for $48 \pm 3$ hours. Gas production is indicative of possible presence of coli forms. Confirmatory tests involved the transfer of inocula from all positive presumptive test tubes into sterile brilliant green broth and incubating at $37^{\circ} \mathrm{C}$ for $48 \pm 3$ hours. The production of gas constitutes a positive confirmatory reaction while absence of gas within this period is indicative of absence of total coli form group of bacteria [19]. The combination of positive tubes was read and the MPN of the total coli forms determined from MPN coli form statistical tables [19].

Thereafter, the remaining greywater was passed through the designed treatment system. The greywater in the flocculation tank was mixed with a commercial flocculant and allowed to stand for 8 hours for sedimentation to take place before finally being passed through a filter (pore size: 0.45 $\mathrm{mm}$, Sartorius) into the disinfection tank. Purified greywater was disinfected using sodium hypochlorite (a commercial disinfectant) and lemon juice. The EC, $\mathrm{pH}$ and MPN of flocculated and disinfected greywater were determined as above. Necessary modifications were carried out to optimize quality of treated greywater.

\section{Field Testing}

A similar system was developed at the Homa Bay study site for use by five households. The households used the system to treat their composite (bath, laundry, and kitchen) greywater and the following measurements were made.

\section{Electrical Conductivity, pH, Salinity and Dissolved Oxygen}

Determination of $\mathrm{pH}$, conductivity, salinity and dissolved oxygen was carried out using appropriate probes of a Multiline P4 (WTW, Weilheim-Germany) meter. These involved transferring a suitable amount to an appropriate container into which the Multiline probes for the measurement of each of the above attributes was lowered into the sample and reading taken after allowing stabilization for a few minutes. Water was collected from each stage of treatment in $250 \mathrm{ml}$ sterilized bottles and then immediately transported to the water research laboratory at the Department of Plant and Microbial Sciences in Kenyatta University and the bacteriological examination of the samples started within six hours as follows:

\section{Screening for Total Coli Forms (TC)}

An amount of $100 \mathrm{ml}$ of greywater sample was aseptically filtered with the aid of a vacuum pump through an aseptic membrane filter with a pore size of $0.45 \mu \mathrm{m}$. The filter was then aseptically transferred from the filtration assembly into a Petri dish containing LES-Endo agar [20]. After incubation at $37^{\circ} \mathrm{C}$ for 24 hours, the bacteria colonies on the membrane filter were counted using a colony counter.

\section{Screening for Fecal Coli Forms (FC)}

An amount of $100 \mathrm{ml}$ of greywater sample was aseptically filtered through a membrane filter. The membrane filter was then aseptically transferred to a sterile snap lid Petri dish containing m-FC broth [19]. The Petri dish was sealed with a waterproof tape, inverted, placed in watertight plastic bag, and incubated in a water bath at $44.5^{\circ} \mathrm{C}$ for 24 hours. Colonies produced by fecal coli form bacteria were blue, and 
Table 1. Physical and Microbial Characteristics of Raw, Flocculated and Disinfected kitchen Greywater from Kenyatta University

\begin{tabular}{|c|c|c|c|c|c|c|}
\hline & Tap Water & Distilled Water & \multirow{2}{*}{ Raw GW } & Flocculated GW & \multicolumn{2}{|c|}{ GW Disinfected With } \\
\cline { 3 - 7 } & & & & $\begin{array}{c}\text { NaOCl } \\
\text { Luice }\end{array}$ \\
\hline \hline Electrical Conductivity $\left(\boldsymbol{\mu S \mathbf { S c m } ^ { - 1 } )}\right.$ & 89 & 81 & 1950 & 1967 & 1946 & 5.92 \\
\hline $\mathbf{p H}$ & 6.95 & 7.01 & 9.34 & 6.4 & 3 & 6.5 \\
\hline Total coli forms $\left(\mathbf{M P N} \mathbf{1 0 0} \mathbf{~ m l}^{-1}\right)$ & 0 & 0 & $\geq 1100$ & $\geq 1100$ & 62 \\
\hline
\end{tabular}

Table 2. Physical and Microbial Characteristics of Raw, Flocculated and Disinfected Laundry Greywater from Kenyatta University

\begin{tabular}{|c|c|c|c|c|c|c|}
\hline & Tap water & Distilled Water & Raw GW & Flocculated GW & \multicolumn{2}{|c|}{ GW Disinfected With } \\
\cline { 3 - 7 } & & & & $\begin{array}{c}\text { NaOCl } \\
\text { juice }\end{array}$ \\
\hline \hline Electrical Conductivity $\left(\boldsymbol{\mu} \mathbf{S c m}^{-1}\right)$ & 89 & 81 & 326 & 495 & 800 & 838 \\
\hline $\mathbf{p H}$ & 6.95 & 7.01 & 6.79 & 5.88 & 6.3 & 0 \\
\hline Total coli forms $\left(\mathbf{M P N} \mathbf{1 0 0} \mathbf{~ m l}^{-1}\right)$ & 0 & 0 & $\geq 1100$ & $\geq 1100$ & 16 \\
\hline
\end{tabular}

were counted using a colony counter. The fecal coli form density was recorded as the number of colony forming units per $100 \mathrm{ml}$ [19].

\section{Screening for Salmonella and Shigella}

Screening for the presence of Salmonella and Shigella was carried out in three successive stages. The first stage of selective enrichment was done using the tetrathionate broth base [19]. After incubation, a loopful of the broth was then carefully streaked on Petri-plate containing SalmonellaShigella (SS) agar and incubated at $37^{\circ} \mathrm{C}$ for 24 hours. Salmonella colonies were colorless with black centers while those of Shigella were colorless and shiny with no black centers. Suspect colonies were subjected to various biochemical procedures to confirm their presence. First, suspect colonies from the presumptive test were streaked on Triple-SugarIron (TSI) agar slants and incubated for 24 hours at $37^{\circ} \mathrm{C}$. A red slant and a yellow butt were indicative of the presence of both Salmonella and Shigella spp. However, gas production (indicated by gas bubbles and a black color) was specific for Salmonella. Further confirmation involved a serological activity test. One drop of the suspected colony was placed on to a white ceramic tile and a drop of thoroughly shaken respective antiserum was added and stirred using a sterile applicator. The tile was rotated slowly and examined for clumping after 1-2 minutes. Agglutination indicated the presence of Salmonella or Shigella respectively [19].

\section{Screening for Vibrio Cholerae}

Presence of Vibrio cholerae was determined in three successive stages. An amount of $1 \mathrm{ml}$ sample was enriched in sterile alkaline peptone water dispensed in $10 \mathrm{ml}$ tubes and incubated for 18 hours at $35^{\circ} \mathrm{C}$ [19]. A loopful of the broth was then carefully streaked on Petri-plate containing Thiosulfate Citrate Bile Salts Sucrose (TCBS) agar and incubated at $35^{\circ} \mathrm{C}$ for 24 hours. Suspect colonies were small in size, dirty yellow with yellow halo in the centre [21]. Serological tests were carried out to confirm the suspect colonies [22]. This involved introducing a colony of suspected $V$. cholera onto a white ceramic tile followed by one drop of thoroughly shaken antiserum suspension. The ceramic tile content was mixed by stirring with a suitable sterile applicator stick. Any agglutination after 5-10 minutes confirmed the presence of V. cholerae.

\section{RESULTS AND DISCUSSION}

The results of the pilot testing of GWT system using greywater $(\mathrm{GW})$ from the two sources in Kenyatta University are presented in Table $\mathbf{1}$ and $\mathbf{2}$ and those for Homa Bay in Table $\mathbf{3}$ and Fig. (2). Physical water quality parameters were similar to previously published data for 'light' GW [23]. The chemical and biological characteristics of GW have been reported to vary widely depending on water source, personal hygiene, cleaning products used among others [24]. In general, GW shares similar chemical and biological characteristics to combined household wastewater, but with comparatively lower concentrations [23]. In the present study, $\mathrm{pH}$ values of $\mathrm{GW}$ from kitchen and laundry sources were significantly $(\mathrm{p}>0.05)$ different with kitchen GW having higher values than laundry GW (Tables 1 and 2). Raw kitchen GW recorded a pH of 9.34, which significantly decreased $(p>0.05)$ to 5.92 and 6.5 when purified by the GWT system and disinfected with sodium hypochlorite $(\mathrm{NaOCl})$ and lemon juice respectively. The $\mathrm{pH}$ of raw laundry GW also decreased but not significantly $(\mathrm{p}<0.05)$ from 6.79 to 6.3 and 6.5 when purified and then disinfected with sodium hypochlorite and lemon juice respectively. In both cases, disinfection with either $\mathrm{NaOCl}$ or lemon juice shifted the $\mathrm{pH}$ to slightly acidic. The $\mathrm{pH}$ of untreated $\mathrm{GW}$ and effluent leaving each treatment stage in Homa Bay were not significantly different $(p>0.05)$ and ranged from 6.33 when flocculated with aluminum sulphate to 8.7 when disinfected 
Table 3. Some Physical and Microbial Characteristics of Tap Water and Raw, Flocculated and Disinfected Composite Greywater from Homa and Limits Set by WHO 1989 Guidelines. Published Data

\begin{tabular}{|c|c|c|c|c|c|}
\hline & Tap Water & Raw GW & Flocculated GW & $\begin{array}{c}\text { GW Disinfected } \\
\text { with } \\
\mathrm{NaOCl}\end{array}$ & WHO/FAO Guidelines \\
\hline Electrical Conductivity $\left(\mu \mathrm{Scm}^{-1}\right)$ & 187 & 1270 & 1266 & 1383 & $<2700$ \\
\hline pH & 7.5 & 6.6 & 6.33 & 8.7 & $6.5-8.4^{\mathrm{b}}$ \\
\hline Dissolve Oxygen $\left(\mathrm{mg} \mathrm{L}^{-1}\right)$ & 5.4 & 0.6 & 5.6 & 5.94 & $>2$ \\
\hline Salinity $\left(\mathbf{m g ~ L ^ { - 1 } )}\right.$ & 0 & 0.4 & 0.4 & 0.5 & $<0.7$ \\
\hline Fecal coli forms (cfu/100 ml) & $5.4 \times 10^{4}$ & $5.4 \times 10^{5}$ & $4.2 \times 10^{3}$ & $2.1 \times 10^{2}$ & $200^{\mathrm{a}}$ \\
\hline Total coli forms (cfu/100 ml) & $2.2 \times 10^{6}$ & $7.3 \times 10^{6}$ & $4.6 \times 10^{6}$ & $2.5 \times 10^{6}$ & $1,000^{\mathrm{c}}$ \\
\hline Salmonella sp. & Present & Present & Present & Absent & Non detectable \\
\hline Shigella sp. & 0 & Absent & Absent & Absent & Non detectable \\
\hline Vibrio cholerae & 0 & Absent & Absent & Absent & Non detectable \\
\hline
\end{tabular}

a WHO 1989 guidelines for public parks and crops likely to be eaten uncooked [31]

b FAO guideline for water quality for irrigation [26]

c WHO/AFESD Consultation, limit for vegetables likely to be eaten uncooked [31]

with $\mathrm{NaOCl}$ (Table 3). The $\mathrm{pH}$ of $\mathrm{GW}$ strongly depends on the $\mathrm{pH}$ of the water supply but cleaning products usually influence the final $\mathrm{pH}$ of $\mathrm{GW}$ discharged [25]. In the present study, raw kitchen GW was observed to have exceptionally high $\mathrm{pH}$ value (9.34) similar to $9.3-10$ values recorded in laundry GW [25]. This has partly been attributed to the sodium hydroxide-based soaps and bleach used. It is recommended that, for easier treatment and to avoid negative impacts on soil and plants when reused, GW should show a $\mathrm{pH}$ in the range of $6.5-8.4[26,27]$. In the present case, the $\mathrm{pH}$ of the effluents from the GWT system were within the above recommended range and would therefore be suitable for irrigation.

Electrical conductivity (EC) is a surrogate measure for total dissolved solids, which provides a measure of the dissolved salt content or salinity. The EC of greywater is typically in the range of $300-1,500 \mu \mathrm{S} \mathrm{cm}^{-1}$, but can be as high as $2,700 \mu \mathrm{S} \mathrm{cm}^{-1}$ [28]. In the present study, the EC of raw kitchen GW increased significantly $(\mathrm{p}>0.05)$ from 326 to 800 and 838 when purified GW was disinfected with $\mathrm{NaOCl}$ and lemon juice respectively while that of purified laundry GW decreased insignificantly $(p<0.05)$ from 1950 to 1846 and $1838 \mu \mathrm{S} \mathrm{cm}^{-1}$ when disinfected with $\mathrm{NaOCl}$ and lemon juice respectively. For Homa Bay, the EC of various categories of $\mathrm{GW}$; raw, flocculated and disinfected ranged from 1,270 to $1,383 \mu \mathrm{S} \mathrm{cm}^{-1}$ (Table 3). Permissible EC limits of GW are strongly dependent on soil characteristics but EC below $1,300 \mu \mathrm{S} \mathrm{cm}^{-1}$ is reported not cause problems in irrigated soils $[29,30]$. However, irrigation with $\mathrm{GW}$ with $\mathrm{EC}$ exceeding $1,300 \mu \mathrm{S} \mathrm{cm}^{-1}$ requires special precautions (use of salt-tolerant plants, well-functioning drainage etc.) [29]. Suggested EC limit for irrigation water is $3,000 \mu \mathrm{S} \mathrm{cm}^{-1}$ with optimal conductivity being below $750 \mu \mathrm{S} \mathrm{cm}^{-1}$ [30]. Flocculation and disinfection improved the dissolved oxygen in GW to a level similar to that of tap water but had no effect on the salinity of GW (Fig. 2).
The results of total and fecal coli forms show that before treatment, the GW is heavily polluted to the extent that it is not acceptable for use on home gardens, according to the WHO guidelines [31]. The mean total coli forms (MPN/100ml) were 3 and 62 for kitchen GW when disinfected with $\mathrm{NaOCl}$ as per the manufacturer's recommendations and lemon juice respectively and a similar trend was observed for laundry GW (Table 2). This indicates the potential use of lemon juice as a disinfectant of purified GW. The level of total coliforms (MPN/100ml) in treated GW indicates that the effluent was suitable for bathing and irrigation as per the WHO guidelines [31]. In Homa Bay, the plate counts and indicator organism concentrations for untreated greywater were high with mean total and fecal coli forms of $7.3 \times 10^{6}$ and $5.4 \times 10^{5} \mathrm{cfu} / 100 \mathrm{ml}$ respectively (Table 3), suggesting human bacterial contamination and also an indication of possible presence of pathogens. The results of total and fecal coli forms screening show that the GWT system was able to treat $\mathrm{GW}$ to a quality suitable for irrigation according to WHO guidelines for reclaimed wastewater use [31]. The GWT system also produced effluent with fecal coli forms (FC) of $2.2 \times 10^{2} \mathrm{cfu} / 100 \mathrm{ml}$ which is lower than $2 \pm 1 \times 10^{5}$ $\mathrm{cfu} / 100 \mathrm{ml}$ obtained using recycled vertical flow constructed wetland (RVFCW) [23]. The treated GW was also within the allowable limits set in the WHO guidelines for the safe use of wastewater in agriculture (for irrigation of crops likely to be eaten uncooked, sports fields, public parks) and the $\leq 200$ fecal coli forms per $100 \mathrm{ml}$ guideline for use in public lawns, such as hotel lawns, with which the public may come into direct contact [32]. Effluent from the GWT system also met the European Union guidelines of $2000 \mathrm{fecal} \mathrm{cfu} / 100 \mathrm{ml}$ for bathing water but fell short of satisfying total coli form standard of $10^{4} \mathrm{cfu} / 100 \mathrm{ml}$ [33]. Although the treatment and disinfection reduced total coli forms to levels $\left(0->2.4 \times 10^{6}\right.$ $\mathrm{cfu} / 100 \mathrm{ml}$ ) that have been achieved using expensive biological aerated filter (BAF) treatment systems [34], the lev- 
els were in exceedance of the guidelines for vegetables to be eaten raw [32] and an improvement in the filtration and disinfection is therefore required.

The characteristics of greywater vary over time and space with three factors affecting its composition; water supply quality, the composition of the system that transports both greywater and drinking water and the activities in the house [13]. Greywater originating from showers and sinks used for hand washing typically have the lowest concentrations of bacteria and chemicals while greywater originating from kitchen sinks is typically higher in bacteria, organic carbon and solids [35]. In many households, greywater originating from kitchen sinks may also contain high concentrations of fats, oils and grease [36]. These characteristics make the use of greywater originating from kitchen sinks challenging since it may not be well suited for reuse in most types of greywater systems and thus for reuse of greywater, separation at the source may be required. Although exclusion of either the bath or shower lowered the concentration of fecal coli forms as both were significant sources of fecal coli forms [37], greywater from separate sources (bath, dish washing and laundry) in Homa Bay showed no significant ( $p>0.05$ ) difference in terms of total and fecal coli forms [38]. Therefore, the exclusion of either sources of greywater is not expected to significantly lower the contamination. However, treatment of kitchen greywater posed a challenge due to high fat and oil content which frequently clogged the sieves during the study and its exclusion is recommended on this basis.

Presence of fecal coli forms is usually considered to be a specific indicator of fecal contamination of water samples as well as the possible presence of pathogenic bacteria [39]. Further evidence for the presence of human fecal contamination in Homa Bay was provided by the ratio of fecal coli form to total coli forms, which exceeded a value of 0.1 [40]. This was confirmed when untreated greywater was analyzed for the presence of the potentially pathogenic bacteria from the genera Salmonella, Shigella and Vibrio and Salmonella sp. was detected (Table 3). Though not detected during the present study, the presence of bacteria from the genera Shigella and Vibrio in greywater from the various cleaning operations in Homa Bay has been confirmed [38]. Positive count of Salmonella (Salmonella veltereden) which is a common species associated with food poisoning from partially cooked meat and shellfish and presumably passed into the greywater by an infected person washing or possibly the washing of uncooked meat in a bathroom washbasin have been found in untreated GW [37]. Fish is a common meal in Homa Bay households and it may be the most likely source of Salmonella sp. The disinfection of treated greywater with $\mathrm{NaOCl}$ was found to be effective in eliminating Salmonella sp.

A note of concern is that fecal and total coli forms were detected in tap water in levels way above the WHO limits which could be a significant source contamination eventually found in greywater. The $2.2 \times 10^{6}$ and $5.4 \times 10^{4} \mathrm{cfu} / 100 \mathrm{ml}$ (Table 3) for total and fecal coli forms respectively is an indication of contaminated drinking water and possible source of frequent outbreak of cholera experienced in Homa
Bay [38]. The presence of fecal coli forms, Escherichia coli and fecal enterococci may indicate a pathogenic risk in potable water as these organisms have previously been used to assess the safety of greywater recycling [41]. However their absence does not necessarily signify that water is pathogen free as this depends both on the type of treatment that has been used [42].

Large-scale GW treatment systems have been developed and some are currently being used by municipalities and housing units. These systems, which include ultrafiltration; direct disinfection; and constructed wetlands, are expensive and technically complex [25] while "the relatively low values of biodegradable organic matter and the nutrient imbalance limit the effectiveness of biological treatment including low cost constructed wetland technologies" [43]. The cost for installing and operating the designed GWT system is low with no energy requirement and thus can be used even in areas without electricity supply. It costs an average of about 30 USD to install the system and 1 USD to recycle 2000 litres of greywater. This compares favourably with US\$ 0.40/litre, the average cost of the treated effluent in Cyprus [44]. Although the GWT system achieved a fecal coli forms reduction efficiency of $66 \%$ compared to $99 \%$ of membrane bioreactor (MBR) technologies [45], the quality of its treated water still met the WHO standards for both irrigation purposes and toilet flushing. However, despite their superior effluent quality, MBR technologies require high investment costs. The system is unsuitable in water scarce residential areas where due to the excessive recycling of the water during household cleaning operations, GW is discharged in low volumes that make treatment option unviable. In cases of space limitation like in hotels or storey buildings, the small footprint of the GWT can outweigh any shortcomings if the proposed improvements in the designed GWT system are carried out. The installation of GWT system in individual houses, block of flats or hotels can eliminate many sanitary problems, such as saturation of soil around absorption pits, the problems of overflow of the septic tanks / absorption pits and the pollution of underground water. However, before GWT systems can become a common feature in residential buildings, improvement and more field testing is essential to ensure safe treatment and use practices.

\section{CONCLUSION}

Reuse of greywater for landscape irrigation can significantly reduce domestic water consumption. Alongside its benefits, there are potential drawbacks to greywater reuse, raising legitimate concerns about the impact on human and environmental health. Hence GW should not be used without treatment because it contains high load of total coli forms and bacterial load including the salmonella. Contamination does occur as the water is handled within the households. The designed low-cost technology for GWT was found to disinfect Salmonella sp in greywater, improve the turbidity and significantly reduce the total and fecal coli forms making the water suitable for subsurface irrigation. Flocculation and disinfection unit requires to be improved to achieve complete removal of all coli forms. There is need to assess if the treatment and disinfection is effective against other microorganisms like viruses that are usually present in greywa- 
ter. The consumable materials used in this system such as flocculants and disinfectants are affordable and locally available in the shops. In fact, lemon juice which is routinely used in the households was found to be an effective disinfectant.

\section{ACKNOWLEDGEMENTS}

The study was made possible by the funding support of the Lake Victoria Research Initiative (VicRes). We wish to acknowledge the constructive suggestions from colleagues in the Greywater treatment and reuse for agricultural production and environmental protection in the Lake Victoria Basin` research project. Our sincere gratitude is due to the communities in Homa Bay for their contributions to the development of this technology, Mr. Jacob Biwott and Mr. Rodney Ogoti for pilot testing the technology and Stephen Gichobi for providing technical support.

\section{REFERENCES}

[1] CSBE (Centre for the Study of the Built Environment), Graywater Reuse in Other Countries and its Applicability to Jordan. CSBE, 2003.

[2] H. Bouwer, "Integrated water management: emerging issues and challenges", Agricultural Water Management, vol. 45, pp. 217-228, 2000.

[3] A. Assayed, "Preliminary investigation on greywater treatments", M.Sc.Thesis. Jordan University, Jordan, 2003.

[4] World Bank. Data and Statistics in Water Supply and Sanitation http://web.worldbank.org. 2005.

[5] G. Lettinga, P. Lens and G. Zeeman, "Environmental Protection Technologies for sustainable development, Lens, G. Zeeman and G. Lettinga, Eds. Alliance House, London, UK. IWA Publishing, 2000.

[6] P. Lens, G. Zeeman and G. Lettinga: Decentralised Sanitation and Reuse: Concepts, Systems and Implementation, IWA Publishing, UK, 2001.

[7] C. Werner, P. Fall, J. Schlick and H. Mang. "Reasons for and principles of ecological sanitation," in Second International Symposium, pp. 23-30, 2003.

[8] E. N. Nolde, "Greywater reuse systems for toilet flushing in multistorey buildings-over ten years experience in Berlin", Urban Water, vol. 1, pp. 275-284, 1999.

[9] K. Kujawa-Roeleveld and G. Zeeman, "Anaerobic treatment in decentralized and source-separation-based sanitation concepts. Reviews in Environmental Science and Bio/Technology, vol. 5, no. 1, pp. 15-139, 2006.

[10] E. N. Nolde and Partner, "Greywater recycling systems in Germany-results, experiences and guidelines" Water Science Technology, vol. 51, no.10, pp. 203-210, 2005.

[11] Fittschen and J. Niemczynowicz, "Experiences with dry sanitation and grey water treatment in the ecovillage Toarp, Sweden", Water Science Technology, vol. 35, no. 9, pp. 161-170, 1997.

[12] B. Jefferson, A. Laine, S. Parsons, T. Stephenson and S. Judd, "Advanced biological unit processes for domestic water recycling", Water Sci. Technol., vol. 43, no.10, pp. 211-218, 2001.

[13] E. Eriksson, K. Auffarth, M. Henze and A. Ledin, "Characteristics of grey water", Urban water, vol. 4, no. 1, pp. 85-104, 2002.

[14] Z. Li, H. Gulyas, M. Jahn, D. Gajurel and R. Otterphohl, "Grey water treatment by constructed wetlands in combination with $\mathrm{TiO}_{2}$ based photocatalytic oxidation for suburban and rural areas without sewer system", Water Science. Technology, vol. 48, no. 11-12, pp. 101-106, 2003.

[15] E. Friedler and M. Hadari, "Economic feasibility of on-site grey water reuse multi-story buildings", Desalination, vol. 190, no. 1-3, pp. 221-234, 2006.

[16] UNESCO, "Water for People: Water for Life. World Water Assessment Programme", The United Nations World Water Development Report, pp. 92-3, 2003.

[17] A. D. Eaton, L. S. Clesceri, and A. E. Greenberg eds, Standard Methods for the Examination of Water and Wastewater, APHA, Washington, DC, 1995.
[18] M. Cheesbrough, "Medical laboratory manual for tropical countries", vol. 2, pp. 212-213, 1985.

[19] APHA, "Standard Methods for the Examination of Water and Wastewater", American Public Health Association, Washington DC, USA, 1998.

[20] Y. Chan, X. L. Han, Y.W. Kan, "Cloning of Nrf1, an NF-E2related transcription factor, by genetic selection in yeast". Proc Natl Acad Sci US, vol. 90, no. 23, pp. 11371-5, 1993.

[21] S. Stavric, and B. Buchanan, "The isolation and enumeration of Vibrio vulnificus from fish and seafoods" in Laboratory Procedure MFLP-73, Health Protection Branch, Ottowa, Canada, 1995.

[22] T. C. Maria, A.E. Bainotti, and A.C. Simonetta, "Survival of Vibrio cholerae 01 in common foodstuffs during storage at different temperatures", Applied Microbiology, vol. 18, no. 5, pp. 277-280, 1994

[23] A. Gross, O. Shmueli, Z. Ronen, E. Raveh, "Recycled vertical flow constructed wetland (RVFCW) - a novel method of recycling greywater for irrigation in small communities and households", Chemosphere, vol. 66, pp. 916-923, 2007.

[24] S. A. Prathapar, M. Ahmed, A. Jamrah, S. Al Adawi, A. Al Harassi and S. Sidiari, "Overcoming constraints for greywater reuse in Oman", Desalination, vol. 186, pp. 177-186, 2005.

[25] B. D. Christova, R. E. Eden and S. McFarlane, "An investigation into greywater reuse for urban residential properties", Desalination, vol. 106, no.1-3, pp. 391-397, 1996.

[26] FAO, "Water quality for agriculture: Irrigation and Drainage paper 29 Rev. 1", Food and Agriculture Organization of the United Nations, Rome, pp. 174, 1985.

[27] US EPA, "Guidelines for water reuse", U.S. Environmental Protection Agency, Washington DC, 2004.

[28] J. M. Y. Burnat and N. Mahmoud, "Evaluation of On-Site Gray Wastewater Treatment Plants Performance in Bilien and Biet-Diko Villages/Palestine," Environment Protection Committee (EPC), 2005.

[29] S. R. Grattan, "Irrigation Water Salinity and Crop Production". Publication 8066, University of California, Oakland, 2002.

[30] T. A. Bauder, G. E. Cardon, R. M. Waskom and J. G. Davis, Irrigation Water Quality Criteria, http://www.ext.colostate.edu/pubs/crops/00506.html, 2004.

[31] WHO: WHO Guidelines for the Safe Use of Wastewater, Excreta and Greywater, Volume IV, Excreta and Greywater Use in Agriculture. Geneva, Switzerland, WHO Press, 2006.

[32] U. J. Blumenthal, D. D. Mara, A. Peasey, G. Ruiz-Palacios and R. Stott, "Guidelines for the microbiological quality of treated wastewater used in agriculture: Recommendations for revising the WHO Guidelines", Bulletin of the World Health Organization, vol 78, no 9, pp. 1104-16, 2000.

[33] S. Surendran and A. Wheatley, "Grey-water reclamation for nonpotable re-sue", Journal CIWEM, vol. 12, pp. 406-413, 1998.

[34] R. Birks, J. Colbourne, S. Hills, and R. Hobson, "Microbiological water quality in a large in-building, water recycling facility", Water Science and Technology, vol. 50, no. 2, pp. 165-172, 2004.

[35] S. Trujillo, A. Hanson, W. Zachritz, R. Chacey, Potential for greywater recycle and reuse in New Mexico. New Mexico Journal. Science, vol. 38, pp. 293-313, 1998.

[36] P. A. Wilderer, "Applying sustainable water management concepts in rural and urban areas: Some thoughts about reasons, means and needs", Water Science and Technology, vol. 49, no. 7, pp. 7-16, 2004

[37] R. Birks and S. Hills, "Characterisation of indicator organisms and pathogens in domestic greywater for recycling", Environmental Monitoring and Assessment, vol. 129, pp. 61-69, 2007.

[38] K. Kotut, E. Chaggu, M. S. Nabacwa, F. Kariuki, C. Nkata and V. Ng`ang`a, "Greywater treatment and reuse for agricultural production and environmental protection in the Lake Victoria Basin" in Lake Victoria Initiative Proceedings of VicRes Pollution and Heavy Metal Cluster Workshop, 2009, pp. 231-250.

[39] R. M. Maier, I. L. Peper and C. P. Gerba, Environmental Microbiology: Academic Press, 2000.

[40] W. Sinton, R. K. Finlay and D. J. Hannah, "Distinguishing human from animal fecal contamination in water: a review", New Zealand Journal of Marine and Freshwater Research, vol. 32, pp. 23-348, 1998.

[41] J. B. Rose, G. S. Sun, C. P. Gerba and N. A. Sinclair,"Microbial quality and persistence of enteric pathogens in graywater from 
various sources household sources", Water Research, vol. 25, no. 1, pp. 37-42, 1991.

[42] C. P. Gerba and J. B. Rose, "The indicator concept in wastewater reclamation: Past, present and future" in the 4th International Symposium on Wastewater Reclamation and Reuse, Mexico City, 2003.

[43] R. Al-Jayyousi, "Greywater reuse: towards sustainable water management”, Desalination, vol. 156, pp. 181-192, 2003.
[44] C. A Kambanellas, "Onsite Grey Water Treatment and Reuse" presentation in International Water Demand Management Conference, Nicosia, Cyprus, 2004

[45] M. Cornelia, R. Scheumann, B. El Hamouri and M. Kraume, "Membrane bioreactor technology for the treatment of greywater from a sports and leisure club", Journal of Desalination, vol. 215, pp. 37-43, 2007.

(c) Kariuki et al.; Licensee Bentham Open.

This is an open access article licensed under the terms of the Creative Commons Attribution Non-Commercial License (http://creativecommons.org/licenses/by-nc/3.0/g) which permits unrestricted, non-commercial use, distribution and reproduction in any medium, provided the work is properly cited. 